\title{
Students perspective on the impact of gender on medical training and future practice
}

This article was published in the following Dove Press journal:

Advances in Medical Education and Practice

8 February 2017

Number of times this article has been viewed

\section{Rahul Rajesh Amin \\ Prashant Bamania}

Faculty of Medicine, Imperial College London, London, UK
Correspondence: Rahul Rajesh Amin Faculty of Medicine, Imperial College London, Kensington, SW7 2AZ, London, UK

Email rahul.r.amin12@imperial.ac.uk

\section{Dear editor}

We read with great interest the study by Van Wyk et al ${ }^{1}$ which explores the beliefs and opinions held by final-year medical students on the impact of gender on their training and the medical profession they were about to enter. As fifth year medical students ourselves, studying at Imperial College London, UK, this was a study we could strongly relate to and as such, we were particularly impressed by some of the findings.

Having just finished our Obstetrics and Gynaecology (OBG) rotation, our experiences highlighted to us the issue of how one's gender affects the training received during medical school. We agree with the findings of the study that there are obstacles to males performing intimate examinations, and even consultations, on female patients. ${ }^{1}$ This especially holds true in a multicultural city like London, where many different social, religious, and cultural beliefs exist. What is particularly noteworthy, however, is that we found that our gender, and status as a medical student, was the biggest contributor to a female patient's reluctance to having a male student examine them, especially during our OBG rotation. This is in contrast to the study's findings that the male student's age was a greater influence than their gender on a patient's decision. ${ }^{1}$ This difference from our experience may be due to cultural beliefs held in countries like South Africa, where this study was conducted, in comparison to the UK. We also noticed that the cultural background of a patient affects whether we, as male students, could examine or even talk to some female patients. Female patients, particularly the elderly, who were of a different cultural background to us were less likely to consent to male students performing basic clinical examinations on them or taking a history. Yanikkerem et $\mathrm{al}^{2}$ supported the notion that some women may prefer being examined by female doctors and commented that religious and cultural beliefs were among the influences for a patient's preference.

The finding that females in particular struggled with elderly male patients who had a different cultural background to them also drew our attention. ${ }^{1}$ From our own experiences on the wards, we have seen how the "incompetent female" idea mentioned by Van Wyk et al ${ }^{1}$ is sparsely present in some elderly male and female patients who resent being treated by females. Again, this may be due to a cultural belief system, an idea echoed in a study by Adudu and $\mathrm{Adudu}^{3}$ who found that some patients preferred male doctors because patients thought they were more hardworking, had superior knowledge, and greater experience. 
Van Wyk et al ${ }^{1}$ also found that some female students mentioned that an advantage of being female enables them to have a better rapport with the patient. From our experience this holds true especially in OBG where our female colleagues were able to build a better rapport by being more gentle, understanding and sympathetic. This may lead to better patient-doctor interaction and a meta-analytic review by Hall and Roter $^{4}$ found that patients of female doctors were less anxious.

In conclusion, we agree with many findings of the study regarding experiencing obstacles during training, which often hold true for both female and male students. In an ideal world, there would be an equal number of female and male doctors in each specialty, and all patients would be equally happy being treated by any doctor regardless of gender. However, in reality, altering people's perceptions of female doctors and changing some of their cultural and religious preferences regarding their doctor's gender may be difficult to achieve.

\section{Disclosure}

The authors report no conflicts of interest in this communication.

\section{References}

1. Van Wyk JM, Naidoo SS, Moodley K, Higgins-Opitz SB. Perceptions of final-year medical students towards the impact of gender on their training and future practice. Adv Med Educ Pract. 2016;7:541-550.

2. Yanikkerem E, Özdemir M, Bingol H, Tatar A, Karadeniz G. Women's attitudes and expectations regarding gynaecological examination. Midwifery. 2009;25(5):500-508.

3. Adudu OP, Adudu OG. Do patients view male and female doctors differently? East Afr Med J. 2007;84(4):172-177.

4. Hall JA, Roter DL. Do patients talk differently to male and female physicians? A meta-analytic review. Patient Educ Couns. 2002;48(3):217-224.

Dove Medical Press encourages responsible, free and frank academic debate. The content of the Advances in Medical Education and Practice 'letters to the editor' section does not necessarily represent the views of Dove Medical Press, its officers, agents, employees, related entities or the Advances in Medical Education and Practice editors. While all reasonable steps have been taken to confirm the content of each letter, Dove Medical Press accepts no liability in respect of the content of any letter, nor is it responsible for the content and accuracy of any letter to the editor.

\section{Publish your work in this journal}

Advances in Medical Education and Practice is an international, peerreviewed, open access journal that aims to present and publish research on Medical Education covering medical, dental, nursing and allied health care professional education. The journal covers undergraduate education, postgraduate training and continuing medical education including emerging trends and innovative models linking education, research, and health care services. The manuscript management system is completely online and includes a very quick and fair peer-review system. Visit http://www.dovepress.com/testimonials.php to read real quotes from published authors.

Submit your manuscript here: http://www.dovepress.com/advances-in-medical-education-and-practice-journal 